\title{
Anselm Heinrich
}

\section{William Gladstone AND THE THEATRE}

William Ewart Gladstone, four times prime minister (1868-74, 1880-5, 1886, and 1892-94), the "greatest colossus of the Victorian Age,"1 the most influential prime minister of the nineteenth century, and the Grand Old Man (G.O.M.) of British politics and statesmanship, seems an unlikely advocate for the theatre. Deeply religious, conservative, and serious, Gladstone is not easily imagined as an avid theatregoer. It is difficult to imagine him supporting the ephemeral, often subversive, and suggestive character of the theatre. And indeed, in his early years Gladstone despised the theatre and called it an "encouragement of sin." 2 As prime minister, he was almost obsessed by a religious zeal; Richard Foulkes has noted that "Few, if any, prime ministers have carried out their role in making senior Church appointments as assiduously as Gladstone did." 3 For members of Victorian Britain's Christian majority, the theatre was anathema and regarded as morally suspect. They were intensely suspicious and saw playgoing as a distraction from religion and as a promoter of frivolity, vanity, and female forwardness. ${ }^{4}$ They linked theatres to "prostitution, juvenile delinquency, idleness, drunkenness and frivolity." In fact, theatres were the "antithesis of the

Dr. Anselm Heinrich is Lecturer in Theatre Studies at the University of Glasgow. Prior to this appointment, he was the Arts \& Humanities Research Council research associate on the Ruskinian Theatre project at Lancaster University. He is the author of Entertainment, Education, Propaganda: Regional Theatres in Germany and Britain between 1918 and 1945 (2007) and coedited (with Katherine Newey and Jeffrey Richards) Ruskin, the Theatre and Victorian Visual Culture (2009). He is currently preparing a monograph on regional theatre for Verlag Ferdinand Schoeningh. His other research interests include émigrés from Nazi-occupied Europe, contemporary German theatre, cultural policy, and national theatres.

I would like to thank the two anonymous readers of an earlier version of this essay for their helpful and constructive suggestions. I would also like to express my gratitude to St Deiniol's Library, Hawarden, for a research grant that facilitated my research there. This research was further supported by a research grant from the Department of Theatre, Film \& Television Studies at the University of Glasgow. 


\section{Theatre Survey}

Victorian world view which prized respectability, gentility, decency, education and uplift." ${ }^{5}$ Until at least the later decades of the nineteenth century, theatre "was widely regarded as the lowliest of the arts, if one at all."6

And yet Gladstone had not only read all the major Shakespearean plays and seen them onstage, he also took a keen interest in theatre more generally and displayed a diverse taste in drama. He regularly attended a wide range of theatres and shows, and he saw hundreds of productions, many more than once. He adored actresses such as Ellen and Kate Terry, Mary Anderson, Sarah Bernhardt, and (especially) Lillie Langtry, whom he met several times. He was a keen admirer of actor Charles Kean and later of actor-manager Henry Irving, who became a family friend, and he often went backstage after performances to congratulate actors on their work. ${ }^{7}$ Gladstone was also interested in other theatrical matters. He read Francis Phippen's biography of Edmund Kean; ${ }^{8}$ Matthew Arnold's Irish Essays, which includes Arnold's influential essay "The French Play in London" (1879), in which Arnold calls for subsidized theatres, a national theatre, and a civic theatre scheme; ${ }^{9}$ and speeches by Bulwer-Lytton and Irving. Perhaps not surprisingly, therefore, but fascinating in the light of current research, Gladstone's dramatic taste was varied. He enjoyed Shakespeare ("a mighty power") and plays produced in French, Italian, or German as much as musicals, operas, melodramas, circus performances, and pantomime. ${ }^{10}$

Despite the evidence, the link between Gladstone and the theatre has been rarely discussed and has only recently generated scholarly interest. ${ }^{11} \mathrm{H}$. C. G. Matthew's masterly two-volume biography of Gladstone features only one page on Gladstone's theatregoing, in a chapter entitled "Behind the Scenes.", Glynne Wickham's essay "Gladstone, Oratory and the Theatre" traces Gladstone's abilities as a speaker and establishes the parallel developments of politicians addressing mass meetings and actors performing in ever-larger theatres. ${ }^{13}$ Wickham intriguingly asserts that this parallel development might have been a reason for Gladstone to change his negative stance toward the theatre in the 1850s, and he rightly points to an 1862 dinner for actor Charles Kean as a crucial turning point in Gladstone's appreciation of the stage. ${ }^{14}$ Wickham convincingly establishes a link between Gladstone and Henry Irving, especially regarding the use of their voices. Although fascinating, Wickham concentrates on one particular issue and does not discuss other aspects of Gladstone's fascination with and support for the theatre. In his magisterial study of Irving, Jeffrey Richards probably offers the best (albeit relatively short) overview of Gladstone and the theatre, in particular concerning the Lyceum Theatre under Irving. ${ }^{15}$ The link between Gladstone and emerging approaches to cultural policy receive even less attention; the two key studies on this issue hardly mention him at all. ${ }^{16}$ The relatively sparse interest in the subject is even more surprising given the fact that Gladstone was clearly seen by his contemporaries as someone who was close to the theatre and sometimes supported and actively advanced its cause. Bernard Shaw linked Gladstone's success as an orator to the fact that he "studied his speech as carefully and with as great powers of application as any actor."17 Leading Victorian theatre critic William Archer noted that " Mr. Gladstone's presence at the play on one memorable, but by no means isolated, occasion, has 
been blazoned by his opponents to all the world."18 Bram Stoker, Irving's business manager at the Lyceum, made it quite clear that Gladstone's visits to the theatre were treated as "gala occasion[s]"19 in honor of the support the prime minister was offering the stage. It might be even be argued that Gladstone's vigorous support of the theatre-even at a time when it was not popular to do so-paved the way not only for an increasing recognition of the performing arts but also for the founding of a national theatre. This article attempts to track Gladstone's fascination with and support for the theatre and place it in a wider context of emerging cultural politics. The following discussion of Gladstone's many links to the Victorian theatre and the protagonists of that theatre aims to provide the foundation for analyzing his wider claims on the role of the performing arts in society and the state's responsibility toward the theatre.

\section{GLADSTONE'S THEATREGOING}

A look through Gladstone's diaries offers insight into the extent and variety of his theatregoing and produces an impressive list of the performances he attended. For example, at the Lyceum he saw Ellen Terry, Henry Irving, and Mary Anderson in Shakespeare but also enjoyed Pygmalion and Galatea and a double bill of The Cup and The Corsican Brothers with its "beautiful mise en scène." 20 Gladstone commented on the "excellent acting" in Ingomar at the Gaiety; ${ }^{21}$ admired ballet at the Alhambra ("the prettiest \& best ballet I ever saw"); 22 attended variety at the Royal Aquarium; ${ }^{23}$ saw Olivia, My Milliner's Bill, Devotion, and Young Mrs Winthrop at the Court; ${ }^{24}$ followed A Pair of Spectacles at the Garrick "with the greatest keenness"; 25 admired the Italian actor Tommaso Salvini in Alexandre Soumet's Il Gladiatore as "manifestly an actor of real greatness" at the Haymarket; ${ }^{26}$ and saw countless other melodramas, comedies, and farces at the Globe, the Haymarket, the Royal Olympic, the Prince of Wales, Sadler's Wells, Her Majesty's, St James's, the Princess's (a theatre Gladstone patronized for nearly forty years), the Vaudeville, and even the Metropolitan Music Hall, although the show he saw there "was certainly not Athenian" and he only stayed for half an hour. ${ }^{27}$ The short length of this visit seems to have been the exception, however, as normally Gladstone remained for the full show, which sometimes lasted for up to four hours. Gladstone regularly attended the opera, for example the first British performance (in Italian) of Richard Wagner's Lohengrin at Covent Garden, "on which there is much to say"; ${ }^{28}$ The Flying Dutchman at Her Majesty's (where he was seated in the royal box and "frequently applauded the singers"); ${ }^{29}$ and many operas by Charles Gounod. At Covent Garden, Gladstone also attended the circus. ${ }^{30}$ And he found pantomime "most laughable."31 Gladstone admired Sarah Bernhardt as an actress "beyond my expectations." $32 \mathrm{He}$ had seen her for the first time in a private performance during her first season in London, he marveled at her "remarkable" performances in Scribe's Adrienne Lecouvreur at the Adelphi ${ }^{33}$ and in Racine's Phèdre at the Gaiety, and he also attended her art exhibition. Gladstone regularly went to plays performed in French and even demonstrated knowledge about the different acting styles of the Théâtre Française. ${ }^{34}$ Similarly, Gladstone sat through two hours of Shakespeare in German when 


\section{Theatre Survey}

the famous Schauspielensemble of the Meininger Hoftheater visited London to produce Wintermärchen (A Winter's Tale) and Othello in $1881 . .^{35}$

Additional information about Gladstone's theatregoing can be gleaned from the diaries of his daughter Mary, who often provides intriguing details about the performances (detailed commentary on acting, set design, and costumes and the relation between text and performance, for example) that are missing from her father's precise, informative, short, and sometimes quite dry diary entries. ${ }^{36}$

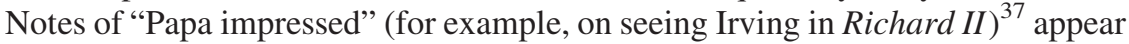
regularly throughout her diary. Mary Gladstone admired Irving just as much as her father, although she thought Ellen Terry the superior actor.

Although Gladstone seems to have patronized the theatre primarily for his own pleasure, he was acutely aware of what the theatre could do for his public image-incidentally in a way that was not too dissimilar to what it did for Queen Victoria. ${ }^{38}$ The general public was intrigued by Gladstone's apparent love for and support of the theatre, and Gladstone was only too happy to acknowledge applause when he was spotted in the audience. By breaking down the barrier between prime minister and the electorate, by being seen in the public sphere, and by being seen as being entertained Gladstone succeeded in gaining admiration and respect-particularly in the provinces, where London always seemed far off. After having seen a production of Hamlet in Liverpool, for example, Gladstone commented that "it was really excellent.-I never was so well received in town." It is not quite clear what pleased him more, the performance itself or the great cheer he received on entering the theatre. ${ }^{39}$ The welcome in Liverpool was not an exception; similar signs of public support seemed to have been quite frequent wherever he went. Mary Gladstone remarked on the occasion of the abovementioned performance of The Flying Dutchman at Her Majesty's that he was given "a fine reception." 40

Interestingly, theatre practitioners actively sought Gladstone's support. Ellen Terry, for example, pleaded with Gladstone to attend her benefit night at the Lyceum Theatre in 1882. Terry claimed that it was "the event of the season" and that she would be "very happy" if Gladstone "would come and beam on us, as you always do when you are at the theatre." She added, "I should feel prouder of your presence than of any other Englishman and would carefully secure you the most comfortable box in the house." ${ }^{41}$ Practitioners attentively watched Gladstone in the auditorium and were clearly relieved when he registered his enjoyment. On the occasion of his production of Othello at Sadler's Wells, for example, E. W. Godwin noticed "Gladstone there in front row of stalls applauding \& app. enjoying." 42 Toward the end of Gladstone's life, practitioners happily made special allowances to accommodate his deteriorating eyesight and increasing deafness. The Lyceum's stagehands arranged for him to take a special seat in the wings that came to be called "Mr. Gladstone's seat." Bram Stoker gives a vivid account of the first occasion of this arrangement in 1890:

When it had been known on the stage that Mr. Gladstone was coming that night to sit behind the scenes the men seemed determined to make it a gala 
occasion. They had prepared the corner where he was to sit as though it were for Royalty. They had not only swept and dusted but had scrubbed the floor; and they had rigged up a sort of canopy of crimson velvet so that neither dust nor draught should come to the old man. His chair was nicely padded and made comfortable. The stage-men were all, as though by chance, on the stage and all in their Sunday clothes. As the Premier came in all hats went off. I showed Mr. Gladstone his nook and told him, to his immense gratification, how the men had prepared it on their own initiative ... and from that time on whenever he came to the theatre he always occupied the same place. $^{43}$

\section{Gladstone and Henry Irving}

Gladstone was an admirer of actor Charles Kean until his death in 1868. From the 1870 s onward, he was increasingly fascinated by Henry Irving (18381905), and he eventually became friends with the great actor. Irving was widely credited with raising the standard of the stage and making it "respectable," with turning it into a "wholesome agency of popular amusement and teaching" thus attracting middle-class audiences. Irving was known to his contemporaries as the manager of a playhouse (the Lyceum) that had become "a national theatre, but without a subsidy." 45 Gladstone was a frequent visitor to the Lyceum and saw Irving's Hamlet five times, as well as his Othello, Richard III, Much Ado about Nothing, Henry VIII, and The Merchant of Venice. He also attended many of his first nights and was invited to sit in Irving's private box. ${ }^{46}$ Gladstone received backstage tours, visited Irving and Terry in their dressing rooms, and was fascinated to learn more about the inner workings of a theatre. According to Bram Stoker, Gladstone even went onstage during a performance once, albeit unintentionally. During a performance of The Corsican Brothers (1881), Irving invited Gladstone backstage between two of his entrances. Bram Stoker recounted what happened:

Mr. Gladstone was exceedingly interested in everything and went all round the vast scene. Seeing during the progress of the scene that people in costume were going in and out of queer little alcoves at the back of the scene he asked Irving what these were. He explained that they were the private boxes of the imitation theatre; and added that if the Premier would care to sit in one he could see the movement of the scene at close hand, and if he was careful to keep behind the little silk curtain he could not be seen. The statesman took his seat and seemed for a while to enjoy the life and movement going on in front of him. He could hear now and again the applause of the audience, and by peeping out through the chink behind the curtain, see them. At last in the excitement of the scene he forgot his situation and, hearing a more than usually vigorous burst of applause, leaned out to get a better view of the audience. The instant he did so he was recognised - there was no mistaking that eagle face- and then came a quick and sudden roar that seemed to shake the building. We could hear the "Bravo Gladstone!" coming through the detonation of hand-claps. ${ }^{47}$ 


\section{Theatre Survey}

More important in the context of this article, Irving shared many of Gladstone's thoughts about the theatre's social and cultural function and its importance in delivering a moral education. The purpose of the theatre was not just to amuse the public — it was "not so restricted"-but it "must always be an indirect mechanism of teaching," Irving claimed in 1898. In short, the theatre was "a potent means of teaching great truths and furthering the spread of education of the higher kind.",48

Both Irving and Gladstone related to a traditional rather than an avantgarde repertoire. The canonical repertoire they required by no means reflected the popular taste for "virtuoso set pieces ... the high color of melodrama, or the variety of burlesques and spectacles." 49 This was in keeping with the goals of those who advocated for a state-subsidized theatre early in the twentieth century. In the first edition of A National Theatre: Scheme \& Estimates, for example, actor-director Harley Granville Barker and critic William Archer made it quite clear that their national theatre would not be a pioneering one. ${ }^{50}$ Although they were happy to include Yeats's Countess Cathleen, Molière's Don Juan, and Maeterlinck's Pelléas and Melisande in its repertoire, they stayed well clear of Tolstoy, Gorky, Ibsen, Hauptmann, and Shaw. ${ }^{51}$ In that respect, the theatre Granville Barker, Archer, and cultural critic Matthew Arnold envisioned-and, in this context, Gladstone and Irving, too-was not to be a place for artistic experiments. On the contrary, "it placed the cultural past as a refuge, or point of nostalgic purity, through which national identity could be preserved." 52 In that sense, although Gladstone's call for a state-aided theatre was certainly visionary and well ahead of his time, his ideas of its repertoire and artistic policy clearly were not. Gladstone's national theatre was to preserve the national heritage rather than foster new writing. He wanted a national theatre to defend Shakespeare's status as a cultural and national icon, one that would become a showcase venue at the heart of the British Empire. And with this thinking, too, Irving concurred.

\section{Gladstone and Wilson Barrett}

Gladstone did not see Shakespeare as the exclusive source for fulfilling the role of educating audiences, however; he looked to other forms of drama, too. A significant connection in this regard is the link between Gladstone and Wilson Barrett (1846-1904). Barrett, one of the leading actor-managers in late Victorian Britain, headed the Princess's Theatre in the 1880s and enjoyed his biggest successes in so-called toga plays-educational melodramas set in ancient Rome and the Roman world. The performances of these plays were noted for their claim to archaeological accuracy and faithful reconstruction of buildings, costumes, and manners. Because they stressed the moral values of Christianity, they were also a powerful ideological tool in late Victorian Britain (for example, in relation to the role of women in society). ${ }^{53}$ In his artistic approach, Barrett combined an unashamedly melodramatic sensibility with an astute head for business. He used detailed realism in staging, had an aptitude for managing large crowd scenes, and had a clear sense of effective scenery. Barrett was arguably most famous for his productions of Claudian (1883) and the spectacular The Sign of the Cross (1895). These productions represent the quintessence of what Barrett wanted to achieve 
with his theatre; he wanted it to both please and educate popular audiences. Gladstone adored The Sign of the Cross not only for its uplifting character and Christian message but also for its social and educational function, especially regarding the working classes. The play features in a noteworthy incident two years before Gladstone's death. Although he was retired from public life and had become physically frail and was losing his hearing and his eyesight, Gladstone went to a performance of The Sign of the Cross, which was put on for him in a special production at Chester in 1896, not far from his residence at Hawarden. Afterward Gladstone wrote to Barrett to thank him:

\begin{abstract}
We have just returned from witnessing the performance of your "Sign of the Cross" to a very crowded afternoon audience in the Theatre at Chester, where we were received with the utmost kindness and courtesy. I was aware that this was a rather daring operation on my part after ceasing to attend Theatres some years ago on account of the condition of my sight and hearing, but I was anxious to render this feeble tribute of acknowledgement to your important and high aimed effort. The acting and the Mise-en-scene appeared to me, as far as I could judge, to do very high credit to the performers and the manager respectively. Though little weight can justly be attached to my judgement I cannot but think that the piece displays a strong dramatic spirit a lofty aim and much judgement and tact as well as force in the management of a difficult dialogue. You seem to me to have rendered, while acting strictly within the lines of the Theatre, a great service to the best and holiest of all causes, the cause of Faith, the audience which showed reasonable self-government even in the smaller points, appreciated most highly the passages which were most directly associated with this service and with the fundamental idea of the piece. And I rejoice to hear of the wide and warm approval which the piece has received most of all because its popularity betokens sound leanings and beliefs in the mass of the people and shows you acted nobly as well as boldly in placing your reliance upon them. I offer you sincere congratulations and thank you for making me with my party your guests today. 54
\end{abstract}

This incident shows not only how much Gladstone supported the theatre and the idea of its educational function by the end of his life but also that the theatre world acknowledged the debt it owed to Gladstone. Corresponding to Gladstone's "throne" at the Lyceum, Barrett's special show had the air of a royal command performance.

Not surprisingly, Barrett was only too happy to use Gladstone's endorsement repeatedly over the following years in his speeches, theatre programs, and publicity material. He reprinted Gladstone's letter in autograph in souvenir programs for The Sign of the Cross. In an unpublished biography of his grandfather, Wilson Barrett (the Younger) quotes parts of Gladstone's letter at length. ${ }^{55}$ In a 1902 speech called "The Moral Influence of the Drama," which has strong religious undertones and reads almost like a sermon, Barrett links both drama and theatre to Christianity, claiming that "true Religion claims all life for God. It turns the light of its Divine principles upon literature, science \& art; It 


\section{Theatre Survey}

gives a right direction to amusement. Religion is not designed to kill our pleasures, or make them less; it is meant to purify \& elevate them; to make them innocent and helpful." To add weight to his claim Barrett quotes "some words of Mr Gladstone": "The Christianity which is now and hereafter to flourish must be in close sympathy with every instinct and need of man ... regardful of the just title of every faculty of our nature; apt to associate with, \& to make its own all good whatever in man which goes to enrich and enlarge the patrimony of our race." 56 Barrett further enlists Tennyson and Ruskin in support for his call for a national drama that "may \& ought to be a moral influence." He concludes that "the true function of theatrical representations should be to purify \& elevate." 57 Although cleverly used here to advance his business (the speech was published and was made widely available), Barrett's claims no doubt would have met with Gladstone's approval. They also illustrate the extent to which Gladstone had come to be seen as an important supporter of the theatre even four years after his death. The speech also pays tribute to Gladstone's continuing popularity. It seems to demonstrate that Gladstone was remembered for his support of a morally uplifting, educational, and national theatre that had a neatly defined function in society.

\section{THEATRE'S ROLE IN SOCIETY}

Gladstone had a clear idea about theatre's role in society as an educational and uplifting force. He linked this understanding with his idea that the state was not "appointed to be conversant with material ends alone." 58 One of the recurring themes in Gladstone's writing concerns the "improvement" of the "working man," not in terms of social mobility but in terms of his morals, his mind, and his skills. ${ }^{59}$ In keeping with Victorian ideals of self-help and individual betterment ${ }^{60}$, Gladstone encouraged the working classes to expose themselves to and learn from the greatest works of the human mind-and this, according to Gladstone, included the theatre. It may not be surprising that Gladstone's increased interest in matters theatrical coincided with his turn to popular politics in the 1860s, although his nickname "The People's William" had been coined in the 1850s. Even though he was a paternalist with a feudal image of society, he was perceived as concerning himself with the miseries of the working man's life. According to Simon Peaple and John Vincent, "his greatest achievement was to bring the working man within the pale of the constitution."61 This move from an aristocratic order to an inclusive constitution was mirrored in Gladstone's ideas that the function of theatre in society was to uplift, provide moral education, and facilitate learning. Therefore, and in contrast to most Victorians, he did not view theatres in purely commercial terms and as business ventures whose chief aim was to produce profits for managers and stakeholders. Nor did he share the prominent and influential view of many Christians who saw playhouses as places of evil. ${ }^{62}$ At a time when theatre was largely held in low regard by the establishment, Gladstone spoke openly on his ideas about its moral purpose.

Gladstone's thinking on this issue developed more clearly in the late 1850s, especially in connection with his admiration of Charles Kean, the most prominent Shakespearean actor of his time. Gladstone wrote to congratulate Kean a few 
days after he saw him as Richard in Richard II in 1857. In response, Kean invited him to visit him at his theatre. ${ }^{63}$ A year later he went to see King Lear twice and called Kean "a very considerable performer." 64 When Gladstone presided over a dinner given to Kean on his retirement from the stage in 1862, he praised Kean "for raising the moral tone of the stage." 65 This event seems to have been a crucial turning point in Gladstone's active support of the stage. Yet Gladstone's interest would be hardly imaginable if the stage itself had not undergone a substantial shift, one that Kean perfectly illustrates and that might help explain Gladstone's "conversion."

By the late 1850s Kean had established himself as London's leading actormanager and his Princess's as the leading theatre. The Princess's had managed to attract a cross section of society and had largely fulfilled its goal of reaching all classes. According to one contemporary critic, its audiences extended from "the Queen in the Royal Box to the artisan in the gallery." ${ }^{.66}$ During this period, some London theatres were substantially renovated, creating richly decorated auditoriums with comfortable seating, expensive carpets and curtains, and the latest in stage technology. Acting was professionalized, and ticket prices were raised. To many commentators, it appeared as if the theatre had gained its "respectability." It had succeeded in wooing the middle class, and according to Matthew Arnold, "our community [was] turning to the theatre with eagerness.",67 Through its mounting of "virtuous" entertainment such as plays by Shakespeare and Molière, educational melodramas, toga plays, and pantomime, theatre was a powerful tool to "better" the lower-middle and working classes, an aim Gladstone was only too keen to realize.

One important aspect of Gladstone's relation to and claims on the theatre is his Christian piety. After having echoed the antitheatrical sentiments of the evangelical majority in Victorian Britain as a young man, Gladstone's ideas of the "cultivation and improvement" an official encouragement of the arts and popular education. This transformation coincided at least in part with changing attitudes within the Church of England in the second half of the nineteenth century, particularly concerning Shakespeare. Christians increasingly acknowledged that Shakespeare's plays needed to be seen in performance in addition to being read. Also, and in marked contrast to earlier decades, Christian commentators increasingly stressed Shakespeare's religious faith, his "conformity as a member of the Church of England" even. ${ }^{69}$ The church played a part in the celebration of Shakespeare's 1864 tercentenary, supporting the so-called toga plays and Wilson Barrett's Sign of the Cross in particular. The educational quality of some of the leading actor-managers' productions recommended the stage further to the church. Playwrights Henry Arthur Jones and Wilson Barrett treated religious subjects onstage and openly vied for the church's support, and Foulkes claims that Irving eventually all but effected "the summation of the reconciliation between Church and the stage." ${ }^{.70}$ At the same time, however, many Christians continued to be hostile toward theatregoing, and Gladstone's active support astonished many. Although his interest in the theatre coincided with a general development, that development received a vital impulse from Gladstone's "conversion" to the stage, because, as Foulkes notes, "the 


\section{Theatre Survey}

endorsement of a convert always carries extra conviction amongst waverers."71 By the late 1870s, Gladstone's support of the theatre's uplifting and educational role was well publicized, although friends and colleagues were still surprised to hear Gladstone "defend plays and the theatre"; "on no subject have his opinions undergone a more complete revolution," his friend Robert Phillimore remarked. $^{72}$

\section{Honors: Actors as Peers of the Realm}

Gladstone never saw the theatre as either an entirely private affair or a purely commercial one. He envisaged a closer connection between the theatre and the state and pursued this idea on different levels. One was official recognition of theatre practitioners as expressed through official honors such as knighthoods. During the nineteenth century, honors had become a way into Britain's elite class. Traditionally, honors had been bestowed on career diplomats, members of the military and the judiciary, politicians, aristocrats, and industrialists for services to the crown and, increasingly, the empire-or sometimes for less noble motives, such as in return for contributions to the coffers of a political party. ${ }^{73}$ At the end of the nineteenth century, as the hunger for titles grew, new honors were introduced but their strict hierarchy kept intact —although claims about their exclusivity could not be entirely upheld.

The arts, and the theatre in particular, were not seen as meriting such recognition, however. It is not surprising, therefore, that campaigns in the press and by politicians for knighthoods for Charles Kean and Samuel Phelps were unsuccessful. Gladstone's approach to awarding honors, however, was different and can again be linked to an emerging and distinctly Victorian cultural politics. In contrast to the prime ministers who had preceded him, Gladstone pressed for "Arts Baronetcies" in the 1880s and 1890s. ${ }^{74}$ Artist Frederick Leighton praised him as the "first among English Prime Ministers" to pay tribute to the arts in this way. ${ }^{75}$ As early as 1883 , Gladstone wondered whether it would be "too audacious" to knight Henry Irving, and two years later he considered a knighthood for Squire Bancroft, an actor-manager. ${ }^{76}$ Gladstone was keenly aware that knighthoods were not an end in themselves but also a recognition from which state and government could profit. When an artist, a composer, or an actormanager at the head of their profession accepted such a reward for his achievements, surely this reflected positively on the government that had suggested the honor. It was essential that the individuals who were honored be gentlemen who were established and respected in their field and who were financially independent. ${ }^{77}$ When Gladstone and others were thinking about honoring Bancroft, it seemed quite important to note that "his fortune would allow him not to act on the stage again,"78 and when he eventually received his knighthood in 1897 he was financially independent and retired. Regarding Irving's possible knighthood other concerns were raised. When offered the honor in 1885, Irving declined, officially because he did want to receive an honor that would put him above his fellow actors. Unofficially, rumors of his relationship to the leading lady at the Lyceum, Ellen Terry, made some cabinet ministers uncomfortable. Although Irving had been estranged from his wife for more than a 
decade, he was still formally married and, therefore, was engaging in "criminal conversation"79 with an actress. Again, artistic concerns do not seem to have featured in the debate.

But Gladstone was adamant in his support for Irving, who was, after all, the leading actor-manager of the time and was internationally renowned and respected. He invited him to his country home at Hawarden, an act that was noted as an important endorsement not only of Irving but also of the theatrical profession as a whole. ${ }^{80}$ Gladstone used his famous Downing Street breakfasts as another way of demonstrating his support for theatre practitioners before official honors came their way. In 1882, for example, Gladstone invited Irving to one of these breakfasts, and three years later, on the occasion of American actress Mary Anderson's appearance as Galatea in W.S. Gilbert's Pygmalion and Galatea, he arranged a large theatre breakfast for Anderson and members of the Lyceum company. ${ }^{81}$ Clearly Gladstone was deliberately preparing the ground for a greater acceptance of theatre and its practitioners within the establishment. His public support for Irving and the way he actively pursued what today may be termed cultural politics eventually paved the way for Irving to be knighted in 1895 .

\section{The Debate over Subsidies}

Until well into the twentieth century, the idea of a state theatre seemed like a strange notion for politicians, theatre practitioners, and the public at large alike. Theatre performances were ephemeral, which made it difficult to generate patronage or subsidies. In contrast, a donated painting or sculpture would be on display forever (or so patrons hoped) and would reflect positively on the generosity of the donors. Until World War II, public funding for the arts was used almost exclusively for maintaining, exhibiting, and expanding the national art collections - an expenditure that, despite some debates, was accepted by the establishment "as a legitimate means of increasing national wealth, both materially and intangibly." 82 Truth be told, most theatre managers cherished their independence and rejected subsidies as a means of political control. Having to cope with economic constraints seemed an altogether lighter burden. Actor Charles Wyndham, for example, resented the "fostering of a State nurse," 83 and theatrical impresario John Hollingshead noted the "English suspicion of institutionalised bureaucracy in state-funded theatres" as part of his argument against state funding. ${ }^{84}$ In contrast to most of continental Europe, in Britain, theatre was not perceived as a national treasure worth spending taxpayers' money on. It was a business that had to make a financial profit. ${ }^{85}$ When Herbert Beerbohm Tree opened his magnificent new theatre, His Majesty's, in 1897which, according to Foulkes, was "the closest Britain was likely to get" to a national theatre ${ }^{86}$ - Bernard Shaw was quick to stress the superiority of the commercial character of the British theatre model. He claimed that while in "some Continental cities, where the theatre rivals the parliament house or the cathedral as a public building, the cost is over $£ 300$ a head, in England we have achieved the commercial triumph of getting the cost down to £7.."87 Whereas in Germany, for example, subsidies to the performing arts came to be seen as a vital part of the state's catalog of responsibilities, almost as important as providing for 


\title{
Theatre Survey
}

schools, hospitals, or the fire service, in Britain there was no consensus that the state had an obligation to pay subsidies from taxpayers' money. Even today, after the "commodification" of the Thatcher years and in present debates about the socalled "creative industries," performing arts companies have to earn this right, and money may be withdrawn if companies do not "perform"- that is, meet financial targets. ${ }^{88}$ In fact, the general public continues to see state funding as suspicious. Richard Foulkes claims that

\begin{abstract}
whilst not denying the instances of royal, aristocratic and civic patronage, it is nevertheless true to say that historically the basis upon which the British theatre operated was commercial. Britain's monarchs did not erect grandiose court theatres, its governments did not aggrandise themselves with imposing state theatres and its municipalities did not minister to their citizens through the medium of subsidised theatres. ${ }^{89}$
\end{abstract}

Foulkes goes so far as to claim that the popular success of Shakespeare, whose plays were exported to a worldwide audience by touring companies (for example, those of Irving and Barrett), was due largely to the commercial nature of the British theatre and could not have been achieved by a subsidized system. ${ }^{90}$ To most commentators, a theatre that operates on a noncommercial footing still seems to be a thoroughly un-British affair. In the nineteenth century, Gladstone was one of the few who begged to differ.

As early as 1841, Gladstone called the state "the safeguard of the best, purest, and truest portions of the common life" and argued that it was responsible for the "cultivation and improvement" of its people. ${ }^{91}$ Sixteen years later, in 1857, after meeting Charles Kean at the Princess's Theatre and receiving a tour of the playhouse, Gladstone noted in his diary that "we had long conversation on the question of Government subvention to the Drama." 92 Although nothing came of Gladstone's idea at that time, he returned to the issue repeatedly over the next decades and spoke about it with others. Matthew Arnold picked up on the idea of subsidies to theatres; so did Henry Irving, who spoke about it often on his extended lecture tours. Irving often noted that he and Gladstone were in agreement on the question of subsidies, thereby adding weight to his demands for a state-subsidized national theatre in the $1890 \mathrm{~s} .{ }^{93}$ The issue of subsidies for the performing arts remained controversial, but it was made more palatable by the link to the "Grand Old Man." ${ }^{94}$ By the same token, the fact that the country's leading actor sought endorsement for his radical ideas from Gladstone shows that the public not only readily accepted that the prime minister should have an opinion on the theatre but also that his opinion carried considerable weight.

\section{A National Theatre}

The campaign for an English national theatre lasted for more than 150 years. The first calls for a playhouse that would foster a national drama and Shakespeare in particular date back to the early nineteenth century. In the early twentieth century the proposals of Harley Granville Barker and William Archer fleshed out the idea. ${ }^{95}$ Finally, in 1949 , the British Parliament agreed to put $£ 1$ 
million toward the building of a national theatre, although it took another fourteen years for the playhouse to open and another thirteen after that to move the national theatre into the new building on the South Bank. However, and in contrast to Germany or France, calls for a national theatre were not necessarily linked to calls for state subsidies for such an institution. ${ }^{96}$ Until the late 1930s, the campaign for a Shakespeare memorial national theatre (widely referred to as SMNT in the early decades of the twentieth century) was left to a small, independent group of aficionados who struggled to secure the necessary funds. The SMNT committee formed just after the turn of the century; its goal was to open a national theatre coinciding with the tercentenary of Shakespeare's death in $1916 .{ }^{97}$ A public subscription was announced, but apart from one major donation of $£ 70,000$, funds came in slowly.$^{98}$ Commentators concluded that the general public clearly did not want a national theatre. ${ }^{99}$ It is interesting to note that calls for a state subsidy as a possible solution to the funding problem rarely featured in the discourse. ${ }^{100}$ For its part, the government almost entirely ignored the SMNT movement, despite its high profile in the press and the involvement of many dignitaries of Edwardian Britain. ${ }^{101}$ Although calls for increased state involvement in cultural matters eventually led in 1913 to a parliamentary debate and a subsequent vote on a state-endowed national theatre, governmental interest in matters theatrical remained almost nonexistent. (The parliamentary vote was defeated, but narrowly so.) ${ }^{102}$ The response to a circular sent to British embassies around the world in 1903 to learn what other countries spent on the performing arts out of public funds was unambiguous. Except for United States and Britain, almost every other industrialized nation paid some kind of subsidy. The class implications of the absence of subsidies rose to the surface when an article in The Times noted that in Britain opera "was purely the amusement of the rich." 103 The article concluded that "the professional man who loves music may be excused for making bitter contrasts between Covent Garden, where he pays at least a guinea for a stall, and the Dresden Opera-house, where he can get as good a seat, and sometimes better music, for four shillings." 104

Still, official policy did not change. When Walter Stephens wrote to Herbert Asquith, at the time the chancellor of the exchequer, in 1906 to ask whether he would be prepared to recommend that the government pay an annual subsidy of $£ 50,000$ for a national repertory theatre in London, the chancellor flatly refused. The Times reported Asquith's response: because of "the large number of objects of much more pressing national importance for which funds are required, the Government would not, in the opinion of Mr. Asquith, be justified in asking Parliament to subsidise a scheme for a National Repertory Theatre at the expense of the taxpayer."105 Although it was certainly noted with interest that the theatrical profession seemed increasingly eager to present itself as "respectable" (and Henry Irving's 1895 knighthood indicates the success of such strategies), politicians by and large continued to stress that theatre and state were two separate entities.

One notable exception to this frame of mind was Gladstone. He would not accept the state of affairs that left theatres to their own devices, nor was he content with some limited state aid to municipal playhouses. Instead, he called 


\section{Theatre Survey}

for a national theatre entirely funded by the taxpayers. Gladstone was thinking about this issue long before others did - and his thoughts were more radical than most. In 1878, he began to speak publicly about his ideas (years before the Shakespeare memorial national theatre movement had formed) and wrote an open letter to the editor of The Theatre, the leading theatre journal of the time. ${ }^{106}$ Gladstone submitted that "the drama requires, in order to its prosperity, some great centre of attraction and of elevation," as with art and the Royal Academy. ${ }^{107}$ This comment, which was originally printed under the "En Passant" section of the journal, proved to be anything but en passant. It became one of the key texts of the national theatre movement. The journal returned to it soon afterward, discussing it in detail in a feature article. The editor concluded that Gladstone "would be not unwilling to see the country provide for the drama the centre of attraction and of elevation which he believes it to require."108 A short time later, journalist and architect George Godwin wrote that the chances of founding a subsidized national theatre had "lately greatly increased," due in large part to Gladstone's overt encouragement. ${ }^{109}$

Matthew Arnold, too, lent his powerful voice in support of state-subsidized national theatre with his seminal 1879 essay "The French Play in London."110 Although Arnold does not explicitly refer to Gladstone, his contribution is clearly part of the momentum Gladstone's remarks had begun, and it is certainly no coincidence that Arnold should have chosen to publish his essay at exactly this time. The influence on Irving may have been even greater. In the early 1880s, Irving had claimed that theatre "must be carried on as a business or it will fail as an art" $" 111$ and that a national theatre would need to be free of state intervention. ${ }^{112}$ But he changed his stance and from the 1890 s onward demanded state support. As an "education medium," the theatre should be given a "proper place in State economy," said Irving in 1898, who bemoaned a situation where up to now "the State ... has, at the best, been indifferent" to the performing arts. ${ }^{113}$ He argued that "the State should exercise an influence, ranging between control and aid" and that the theatre "should distinctly be in some degree encouraged by the State or by municipalities."114 Irving openly acknowledged the link between his thinking and that of Gladstone. When he called for subsidized theatres in a speech in 1894 he was keen to mention that Gladstone endorsed his idea, even anticipated it. ${ }^{115}$ Irving asserted that although it would be praiseworthy if a millionaire spent his money to endow a theatre, "it would be more to the advantage of the community to feel that the theatre was a department of public service than to see it dependent on individual beneficence [as] libraries, museums and picture-galleries flourish under this civic rule, and I see no reason why a municipal theatre should not be equally advantageous." Irving referred to Gladstone's thinking as an endorsement of his own ideas: "I remember that in an interesting conversation I had with Mr. Gladstone on this subject, he expressed the opinion that ... such an experiment as I have sketched to you would have an excellent chance of commanding public favour." 116 Almost twenty years after Gladstone's initial statement in favor of a subsidized national theatre, he was seen as the authority on the subject, an advocate one could return to for substantial (and much-needed) support for far-reaching demands. 
Gladstone's statement also proved highly influential for the supporters of the national theatre movement. In the late 1880s, royal command performances had begun again, but they happened only intermittently, and then at one of the royal palaces and not in London itself. Such performances were increasingly criticized for the monarchy's apparent lack of interest in raising the standards of national drama. It was in this context that the idea of a theatre funded by public money gained momentum. In 1889, The Era claimed that the "lighter forms of dramatic entertainment" that the Court asked for in command performances were not representative and suggested that royalty patronize "the more solid and elevated forms of English dramatic art" instead. ${ }^{117}$ Other commentators went further and asked, "what had the Crown done in the last 100 years to raise the standard of the National Theatre?"118 It seemed clear that the monarchy could not be counted upon to support an educational theatre rather than one shaped solely by commercial considerations. But after Gladstone's intervention, it appeared that it was in fact the government that would be prepared to do just that.

\section{CONCLUDING REMARKS}

Gladstone's love for the drama is noteworthy and his active support of the theatre in general is significant. But it is his initiative regarding the founding of a state-subsidized national theatre and his centrality in the subsequent debates on that topic that are particularly astounding. Gladstone significantly contributed to a change in the public's perception of the theatre. Glynne Wickham has emphasized this achievement particularly with respect to actors and acting, noting that "it is to Gladstone ... that credit must be given for effecting this dramatic reversal in the status of a much-aligned profession in twentieth-century society." 119 But, more important, Gladstone also prepared the ground for wider changes in attitude that ultimately contributed to the general public's increasing receptivity to state support for the arts that included, for the first time, subsidies to the theatre. Without Gladstone's interventions it is difficult to imagine Parliament even coming close to endowing such a national theatre, as it did in 1913. One could even with some justification claim an even more far-reaching effect of his thinking when the idea of a state-funded national theatre returned to the agenda in 1942, this time with tangible results. The British war effort in World War II was never solely aimed at destroying Nazi Germany. For the British government and for the majority of the British people it was also a fight for the survival of democracy, liberalism, and freedom. It was also a fight for the survival of the British way of life, of its traditions and culture, of Shakespeare, Chaucer, and Elgar. As literary critic George Wilson Knight wrote during the war in This Sceptred Isle, "England must always return [to Shakespeare's words] in times of peril." ${ }^{120}$ World War II eventually produced a climate conducive to state subsidies to the performing arts in a way that might have been envisaged by Gladstone himself, in particular because receiving subsidies from CEMA (the state-funded Council for Encouragement of Music and the Arts) was linked to the educational quality of theatre programs. ${ }^{121}$ The theatre, then, seems to have represented a fascinating link to one of the pillars of Gladstonian liberalism, one that was "based on a stable, moral order, founded on an alliance between the great 


\section{Theatre Survey}

landed estates and the church." 122 Gladstone's ideal that the state should provide for a morally uplifting and educational theatre almost seems to reconcile these seemingly different agendas. A theatrical repertoire that avoided the controversial social drama of the late nineteenth and early twentieth centuries and instead helped sustain the political and social status quo served this bill perfectly.

Put in a different context, Gladstone's interest and involvement in the theatre points to a wider phenomenon in Victorian society, an issue that also relates to recent theatre historiography. ${ }^{123}$ A picture is emerging of leading Victorians who failed to conform to alleged distinctions between "high" and "low" culture, between literary drama and popular entertainment. Gladstone was not the only member of the elite who appreciated a range of theatrical performances. In addition to the Prince and Princess of Wales, Lord Lytton, Lord Salisbury, and Lewis Carroll regularly went to the theatre. John Ruskin's theatrical taste was as broad as Gladstone's. ${ }^{124}$ Queen Victoria loved French theatre and Italian opera as well as melodrama, pantomime circus, and General Tom Thumb's impersonation of Napoleon and hornpipe dances. A detailed look at the theatregoing of Lord Acton and even Benjamin Disraeli might also be rewarding. It is to be hoped that further investigations into the extent of and the particular agendas behind these individuals' theatregoing will continue to question orthodox notions of nineteenthcentury culture, which have tended to concentrate entirely on "high" art and have established a narrative of the triumphant emergence in late Victorian Britain of modern drama from a worn-out popular theatre that was devoid of any aesthetic value. The case of Gladstone illustrates the futility of such orthodox approaches and challenges their binary oppositions.

\section{ENDNOTES}

1. Quote from the dust jacket of Richard Shannon, Gladstone, vol. 1: 1809-1865 (London: Hamish Hamilton, 1982).

2. Diary entry for 19 December 1832, in The Gladstone Diaries: With Cabinet Minutes and Prime-Ministerial Correspondence, 14 vols. (the last, indexes), ed. M. R. D. Foot (vols. 1, 2) and H. C. G. Matthew (vols. 3-4 with Foot, vols. 5-14 solo) (Oxford: Clarendon, 1968-94) [hereafter, GD], vol. 1 (1968), 1825-1832 [hereafter, GD 1; each volume will be treated similarly].

3. Richard Foulkes, Church and Stage in Victorian England (Cambridge: Cambridge University Press, 1997), 240.

4. See, for example, William Adamson, The Theater: Its Influence on Actors and Audience: A Lecture (Edinburgh: Andrew Elliot, 1883). Answering the question of whether it was "possible to reform the theatre, and make it the centre of an elevating influence," Rev. Adamson claimed that this "has been tried again and again, without success... . The reason being, the evil is essential, not accidental; and if this is the case, permanent reformation is impossible" (29-30).

5. Jeffrey Richards, Sir Henry Irving: A Victorian Actor and His World (London: Hambledon \& London, 2005), 66.

6. Foulkes, Church and Stage, 241.

7. See, for example, the entries for 24 July 1879, in GD 9 (1986): January 1875-December 1880; 3 January 1881, in GD 10 (1990): January 1881-June 1883; and 9 June 1887, in GD 12 (1994): 1887-1891. Gladstone personally congratulated Frank Benson on his production of Aeschylus' Agamemnon at Oxford University in 1881.

8. Francis Phippen, Authentic Memoirs of Edmund Kean (London: Printed for J. Roach, 1814). 


\section{William Gladstone and the Theatre}

9. Matthew Arnold, "The French Play in London," Nineteenth Century 6 (August 1879): 228 43; reprinted in Irish Essays, and Others (London: Smith, Elder, \& Co., 1882), 208-43. See the entry for 5 April 1882, GD 10; and that for 19 January 1886, in GD 11 (1990): July 1883-December 1886.

10. Entry for 5 May 1859, GD 5 (1978): 1855-1860. Interestingly, Gladstone's reading was similarly diverse. It was not just policy-oriented literature he read—and Gladstone read a lot—but also books on theology, history, biography, and monarchy as well as "many lesser works which made an impact in their time," including Ben-Hur and the Kama Sutra. See H. C. G. Matthew, Gladstone: 1875-1898 (Oxford: Clarendon, 1995), 275-6.

11. Some of the standard biographies do not mention the Gladstone theatre link at all, such as Roy Jenkins, Gladstone (London: Macmillan, 1996); Shannon, Gladstone, vol. 1; and Richard Shannon, Gladstone: [vol. 2] Heroic Minister, 1865-1898 (London: Allen Lane, 1999). The contemporary biographies are not much better; see, e.g., George Barnett Smith, The Life of the Right Honourable W. E. Gladstone, 2 vols. $2^{\text {nd }}$ ed. (London: Cassell, 1879); and John Morley, The Life of William Ewart Gladstone, 3 vols. (London: Macmillan, 1903).

12. Matthew, 277-8 (the second of the two volumes).

13. Glynne Wickham, "Gladstone, Oratory and the Theater," in Gladstone, ed. Peter J. Jagger (London: Hambledon, 1998), 1-32.

14. See ibid., 20 and $24-26$.

15. See Richards, Sir Henry Irving: A Victorian Actor, 77-82.

16. Janet Minihan, The Nationalization of Culture: The Development of State Subsidies to the Arts in Great Britain (London: Hamish Hamilton, 1977); Jörn Weingärtner, The Arts as a Weapon of War: Britain and the Shaping of National Morale in the Second World War (London: I. B. Tauris, 2006).

17. Bernard Shaw, Our Theatres in the Nineties, 3 vols. (London: Constable, 1948), 3: 108.

18. William Archer, About the Theatre: Essays and Studies (London: Fisher Unwin, 1886), 5.

19. Bram Stoker, Personal Reminiscences of Henry Irving, 2 vols. (London: Heinemann, 1906), 30

20. Entry for 3 January $1881, G D 10$.

21. Entry for 27 April 1883, GD 10.

22. Alfred Thompson's Yolande; entry for 25 September 1877, GD 9.

23. Entry for 2 July $1877, G D 9$.

24. Entry for 20 July 1878, GD 9; and entries for 30 April 1884, 17 May 1884, and 18 November 1884, GD 11.

25. As noted by Sir Edward Walter Hamilton, former private secretary to Gladstone (18801885), in his unpublished diary (held at the British Library), entry 18 March 1890 (also referred to in $G D$ 12, 279 (note 1).

26. Entry for 7 May $1875, G D 9$.

27. Entry for 21 July $1877, G D 9$.

28. Entry for 8 Mary $1875, G D 9$.

29. As noted in the Daily News, 11 March 1882, 5.

30. Gladstone noted in his diary on 23 February 1889 that he stayed at the afternoon circus performance for ninety minutes. GD 12 .

31. On the occasion of Little Goody Two Shoes; entry for 22 January 1863, GD 6 (1978), $1861-1868$.

32. Entry for 23 June $1879, G D 9$.

33. Entry for 28 July 1887, GD 12.

34. He remarked in his diary that their "style of acting has altered since my earliest recollections being more vehement and demonstrative. The play was Hernani. M. Maubant (Duc de Silva) was nearest (I thought) to the older school." Entry for 17 October 1879, GD 9.

35. Entry for 17 June 1881, GD 10.

36. Regarding a production of Othello at the Lyceum, for example, she remarked that she "felt it all, every word, marvellous.... All one's breath seemed taken away in awe and admiration of the 


\section{Theatre Survey}

conception. Iago's character specially strikes one as a superhuman masterpiece. . . It is awfully sad." Entry for 18 February 1876, in Mary Gladstone (Mrs. Drew): Her Diaries and Letters, ed. Lucy Masterman, 2d ed. (London: Methuen, 1930), 103.

37. Entry for 5 May 1877, in ibid., 122.

38. Richard Schoch argues that "without the Queen, the stage would have remained morally suspect; without the stage, the Queen would have seemed more distant and remote"; Richard W. Schoch, Queen Victoria and the Theatre of Her Age (Basingstoke, Hampshire: Palgrave, 2004), xiii.

39. Entry for 17 November 1876, GD 9.

40. See diary entry for 10 March 1882, in Mary Gladstone, ed. Masterman, 242.

41. Terry to Gladstone, 20 June 1882, Gladstone Papers, 44475, 305, British Library, London (hereafter, Gladstone Papers).

42. Entry for 1 October 1880, Godwin Diary 1880, Godwin Collection, AAD 4/5-1980,

Archive of Art and Design, Victoria and Albert Museum, London.

43. Stoker, 2: 29-30, 32.

44. T. H. S. Escott, Social Transformations of the Victorian Age (London: Seeley \& Co., 1897), 209.

45. Austin Brereton, The Life of Henry Irving, vol. 1 (London: Longmans, Green \& Co., 1908), 297.

46. See Alfred Bryan's drawing in Wickham, 29.

47. Stoker, 1: 167-8.

48. On receiving an honorary doctorate; speech delivered by Irving at Cambridge on 15 June 1898, quoted in Sir Henry Irving: Theatre, Culture and Society—Essays, Addresses and Lectures, ed. and intro. by Jeffrey Richards (Keele, Staffordshire: Ryburn Publishing and Keele University Press, 1994), 223, 227-8.

49. Loren Kruger, The National Stage: Theatre and Cultural Legitimation in England, France, and America (Chicago: University of Chicago Press, 1992), 89. Kruger intriguingly discusses the target audiences of the different schemes for a national theatre during the nineteenth century and concludes that, despite some differences in their approaches, the protagonists of the movement envisaged as patrons "leisured amateurs in confident possession of their patrimony" (101). They did not intend to open up "their" national theatre to new (i.e., working-class) audiences outside the "leisured" middle class.

50. See William Archer and Harley Granville Barker, A National Theatre: Scheme \& Estimates (London: Duckworth, 1907).

51. Ibid., 44. See also Kristen Guest, "Culture, Class, and Colonialism: The Struggle for an English National Theatre, 1879-1913," Journal of Victorian Culture 11.2 (2006): 281-300, at $290-1$.

52. Guest, 296.

53. The most significant successes of this vogue were Tennyson's The Cup (1881), W. G. Wills's Claudian (1883), Wilson Barrett's The Sign of the Cross (1895), and W. S. Gilbert's Pygmalion and Galatea (1871). See David Mayer, ed., Playing out the Empire: "Ben-Hur" and Other Toga Plays and Films, 1883-1908-A Critical Anthology (Oxford: Clarendon Press, 1994); and James Michael Thomas, "Wilson Barrett: Actor-Manager-Playwright" (Ph.D. diss., University of Texas at Austin, 1975 [Ann Arbor, MI: UMI Research Press, 1984]).

54. Gladstone to Barrett, 8 August 1896, Wilson Barrett Collection, Harry Ransom Humanities Research Center, University of Texas at Austin (hereafter, Wilson Barrett Collection). This letter and other material from this collection are reproduced here with many thanks to Professor Kate Newey, University of Birmingham.

55. See Wilson Barrett (the Younger), “... And Give Me Yesterday,” typescript of biography by Wilson Barrett's grandson, ca. 1960s, 228-9, Wilson Barrett Collection.

56. Speech delivered at St. Paul's Cathedral, Dunedin, New Zealand, 12 January 1902, Wilson Barrett Collection. (Underlines in the original speech are shown in italics.) 


\section{William Gladstone and the Theatre}

57. Ibid.

58. William Ewart Gladstone, The State in Its Relations with the Church, 4th rev. ed., 2 vols. (London: John Murray, 1841), 1: 151.

59. See Simon Peaple and John Vincent, "Gladstone and the Working Man," in Gladstone, ed. Peter J. Jagger (London: Hambledon, 1998), 71-84, at 72.

60. Samuel Smiles, Self-Help, with Illustrations of Character, Conduct, and Perseverance, ed. and with intro. by Peter W. Sinnema (Oxford: Oxford University Press, 2002). Self-Help was first published in 1860 .

61. Peaple and Vincent, 83.

62. For a good discussion of Christian rejection of the theatre, see Richards, Sir Henry Irving, $393,395-6$.

63. Entries for 22, 25, and 30 April 1857, and 12 May 1857, all in GD 5 (1978), 1855-1860.

64. Entries for 29 May 1858 and 10 June $1858, G D 5$.

65. Shannon, 1: 392. See also Smith, 2: 484, 486; and Morley, 2: 528.

66. Quoted in Richard W. Schoch, "Theater and Mid-Victorian Society," in Cambridge History of British Theatre, vol. 2: 1660 to 1895, ed. Joseph Donohue (Cambridge: Cambridge University Press, 2004), 331-51, at 342.

67. Arnold, "French Play in London," 240 (Irish Essays, 235). Even to Victorians, "respectability" was a bit of a slippery term, although most accounts of respectable behavior include "cleanliness, hard work, self-sufficiency, thrift, piety, deference to authority and even correct speech"; Schoch, "Theater and Mid-Victorian Society," 331. Concerning changes in audience composition, see also Joseph Donohue, "Theatres, Their Architecture and Their Audiences," in Cambridge History of British Theatre, 2: 292-308.

68. Gladstone, State in Its Relations, 81.

69. William Wordsworth as quoted in Foulkes, Church and Stage, 103.

70. Ibid., 211.

71. Ibid., 240.

72. Entry from Phillimore's diary as referred to in editorial annotation in GD 9, 286 (note 1, referring to Gladstone's entry on 26 January 1878). Robert Joseph Phillimore (1810-1885), judge, jurist and Peelite, was one of Gladstone's best friends. The diaries form part of the Papers of Sir R.J. Phillimore collection held at Christ Church Library, Oxford.

73. Indeed, as David Cannadine points out, Britain had "the most complex and comprehensive titular hierarchy in existence anywhere in the western world"; Cannadine, Ornamentalism: How the British Saw Their Empire (London: Allen Lane, 2001), 98.

74. See Shannon, [2]: 363.

75. See Leighton to Gladstone, 16 June 1885, Gladstone Papers, 44491, 130. Similarly, Oscar Wilde stressed "my deep admiration and loyalty to one who has always loved what is noble and beautiful and true in life and art, and is the mirror of the Greek ideal of the statesmen"; Wilde to Gladstone, 21 July 1881, Gladstone Papers, 44470, 239.

76. See Shannon, [2]: 363.

77. Contemporary commentators urged that for the sake of propriety only retired actors of independent means should be knighted and not "young leviathans [who] disport[ed] themselves in the sun of popular favour"; Academy, 26 June 1897. The danger that a knighted actor could face bankruptcy a few years down the line was too great in the context of the financial instability of the theatre industry. And to have a knighted an impoverished actor-manager would simply have been unacceptable.

78. Henry Labouchere to Gladstone, 9 June 1885, Gladstone Papers, 44491, 77.

79. The term "criminal conversation" usually denoted the crime of adultery.

80. Mary Gladstone recorded her impression of Irving as a walking companion after this visit: "Irving came to luncheon.... Afternoon walked with G.O.M., Ld. Derby and Irving, a dead failurein vain had hoped his long, thin legs would fly over the Park. For an hour and $\frac{1}{4}$ we dawdled round the house, damp and chilly, the topics never rising above trees, soil, atmosphere. Irving walks $\frac{1}{4}$ of a mile 


\section{Theatre Survey}

an hour. What a brilliant walk it ought to have been." Diary entry for 9 October 1883, in Masterman, Mary Gladstone, 295.

81. See entries for 29 June 1882, GD 10, and 23 April 1885, GD 11. See also Matthew, 277.

82. Minihan, 154.

83. Wyndham, letter to the editor, Daily Telegraph (London), 26 March 1908.

84. Richard Foulkes, Performing Shakespeare in the Age of Empire (Cambridge: Cambridge University Press, 2002), 109.

85. In his magisterial 824-page study of Victorian Britain, Theodore Hoppen devotes less than three pages to the theatre, and those pages focus on salaries paid and profits made; Theodore

K. Hoppen, The Mid-Victorian Generation, 1846-1886 (Oxford: Clarendon, 1998), 391-3. See also Tracy C. Davis, The Economics of the British Stage, 1800-1914 (Cambridge: Cambridge University Press, 2000).

86. Foulkes, Performing Shakespeare, 132.

87. Shaw, Our Theatres in the Nineties, 3: 117.

88. A recent example is the English National Opera (ENO), which was reported to face job losses. Rather than lamenting the possible threat to this flagship institution, the press pointed to the ENO's repeated calls for public funds without changing its structure (see "Bloodbath at English National Opera," The Daily Telegraph, 18 January 2003) and appeared relieved that the Arts Council eventually denied the ENO the chance to approach them "cap in hand" again (see "Cash Crisis Forces ENO To Axe 45 Jobs," The Guardian, 24 February 2007).

89. Foulkes, Performing Shakespeare, 1.

90. See ibid., 4.

91. Gladstone, State in Its Relations, 78, 81.

92. Entry for 12 May 1857, GD 5.

93. Irving's presidential address on 26 September 1894 to the Walsall Literary Institute, quoted in Sir Henry Irving: Theatre, Culture and Society, ed. Richards, 212. The speech was originally published in The Theatre, December 1894.

94. The opinion of the majority was perhaps best summarized by The Era, which argued that "free trade is good in the long run whatever people may say"; The Era, 8 June 1879, quoted in Foulkes, Performing Shakespeare, 109.

95. In addition to Archer and Granville Barker's joint publication, see Harley Granville Barker, A National Theatre (London: Sidgwick \& Jackson, 1930).

96. Archer and Granville Barker cautiously commented on the possibility of state funding for their proposed national theatre but deemed this both unlikely and unnecessary, as they expected sufficient funds to be raised by private donations.

97. For a summary of the movement's history, see "National Theatre: A Site on the Bedford Estate: The Shakespeare Memorial," The Times, 19 December 1913; Geoffrey Whitworth, The Making of a National Theatre (London: Faber \& Faber, 1951); and Richard Foulkes, The Shakespeare Tercentenary of 1864 (London: Society for Theatre Research, 1984).

98. The committee wanted to raise $£ 500,000$, estimating "that the site ... is likely to cost some $£ 100,000$, the building and equipment $£ 150,000$, and that an endowment fund will be required amounting to £250,000"; "Shakespeare Memorial National Theatre," The Times, 23 October 1909.

99. See, for example, David Fairweather, "Over the Footlights," Theatre World, January 1936, 3, which is discussed in Anselm Heinrich, Entertainment, Education, Propaganda: Regional Theatres in Germany and Britain between 1918 and 1945 (Hatfield: University of Hertfordshire Press, 2007), 68 n. 117.

100. One notable example was a call for the institution of a ministry of fine arts modeled on the French example. See Wynford Dewhurst, Wanted: A Ministry of Fine Arts (London: Hugh Rees, 1913).

101. See "National Theatre: A Site on the Bedford Estate: The Shakespeare Memorial"; and Whitworth, 38-63. 


\section{William Gladstone and the Theatre}

102. See The Parliamentary Debates (Official Report), 5th Series, vol. 52, Third Session of 30th Parliament of the United Kingdom of Great Britain and Ireland, House of Commons, Third Volume of Session 1913, Comprising Period from Monday, 21st April 1913, to Thursday, 8th May, 1913 (London: HM Stationery Office, 1913), 454-94.

103. See The Times, 28 December 1903, 7.

104. Ibid.

105. The Times, 14 March 1906; see also 21 March 1906.

106. Entry for 9 March 1878, GD 9.

107. Gladstone, Letter to the Editor, The Theatre, 13 March 1878, 103.

108. "A Subsidised Theatre for London," The Theatre, 1 August 1878, 8.

109. George Godwin, “The National Theatre Question,” The Theater, 1 December 1878, 349. This article was based on a public lecture Godwin had presented at the Social Science Congress. See also the journal's lead article, "The Past Year at the Theatres," 1 January 1879, 399.

110. See note 9 .

111. Irving, speech to the Edinburgh Philosophical Institution on 8 November 1881, quoted in Richards, Sir Henry Irving: A Victorian Actor, 89.

112. Irving, speech at the Social Science Congress in 1878, quoted in Whitworth, 31-3.

113. Irving, speech at Cambridge on 15 June 1898, quoted in Sir Henry Irving: Theatre, Culture and Society, ed. Richards, 223, 227.

114. Quoted in ibid., 228-9. A few years later, at a speech in Buffalo, New York, in 1902, Irving claimed that "I doubt not that by and by every great city will have its own theatre built by its municipality”; ibid., 234.

115. Irving, presidential address to the Walsall Literary Institute, 26 September 1894, originally published in The Theatre, December 1894; reprinted in Sir Henry Irving: Theatre, Culture and Society, ed. Richards, 206-12.

116. Ibid., 212.

117. See The Era, 4 May 1889.

118. "Mr. Stead on the Theatre," The Times, 14 January 1905.

119. Wickham, 28.

120. G. Wilson Knight, This Sceptred Isle: Shakespeare's Message for England at War (Oxford: Blackwell, 1940), 1.

121. CEMA was a government-funded organization that subsidized performing arts companies, acted as an agent for ensembles, and drew up funding schemes. It received rapidly increasing funds from the Treasury and in 1942 took over the Theatre Royal Bristol as the first British state theatre. CEMA was the forerunner of the Arts Council, which was founded in 1946. It aimed at creating "permanent, educated audiences all over the country"; CEMA, The Fifth Year: The End of the Beginning-Report on the Work of CEMA for 1944 (London: CEMA, 1945), 32. See also Weingärtner.

122. Peaple and Vincent, 74.

123. See, for example, Jacky Bratton, New Readings in Theatre History (Cambridge: Cambridge University Press, 2003); and Interpreting the Theatrical Past: Essays in the Historiography of Performance, ed. Thomas Postlewait and Bruce A. McConachie (Iowa City: University of Iowa Press, 1989).

124. For recent studies on Ruskin, see Ruskin, the Theatre, and Victorian Visual Culture, ed. Anselm Heinrich, Kate Newey, and Jeffrey Richards (Basingstoke, Hampshire: Palgrave, 2009); and Sharon Aronofsky Weltman, Performing the Victorian: John Ruskin and Identity in Theater, Science, and Education (Columbus: Ohio State University Press, 2007). 